\title{
Business Ethics of Malay Businesspeople
}

\author{
[Norasmah Othman \& Norsaidah Alias]
}

\begin{abstract}
In this era of globalization, ethical matters are overlooked by many in everyday life. This also holds true for businesses, as is evident in news reports on the unethical conduct of businesspeople, such as the breach of trust, cheating, and other irresponsible practices. Such events raise the question of how well business ethics is practiced by businesspeople. Therefore, we conducted a study to determine the extent to which business ethics are practiced by businesspeople owning small and medium enterprises (SMEs). We also reviewed how business ethics practiced among the Bumiputera and non-Bumiputera-owned SMEs differ. We employed a questionnaire survey to obtain data. One hundred respondents were chosen as the sample. The data were analyzed using descriptive and inferential statistical tools. The findings show that the level of business ethics practiced among Bumiputera and non-Bumiputera-owned SMEs are high for personal values and moderately high for social responsibility management, ways of conducting business, and interacting with others in business settings. The data also show that there is no difference in the practice of business ethics between the Bumiputera and non-Bumiputera businesspeople, except in their way of conducting business, where the Bumiputera businesspeople are found to be more ethical. Though the mean difference is small, this indicates that Bumiputera businesspeople are more concerned about ethics than non-Bumiputera businesspeople are. The implications of this study are relevant to the stakeholders in the entrepreneurship training programs. The study implies that people should be exposed to business ethics to avoid unhealthy business practices in Malaysia.
\end{abstract}

Keywords- Ethics, business, small and medium enterprises (SMEs), practice of business ethics

\section{Introduction}

Businesspeople of the twenty-first century must be highly committed towards practicing ethics. In line with the challenges of globalization and trade liberalization, businesspeople are required to display strong commitment to ethics as it helps them maintain their credibility and image and the reputation of their business in the eyes of the public, the customers, and the stakeholders [1], [2]. Therefore, every businessperson should seek to develop, implement, and evaluate his or her actions and decisions in line with ethical requirements. Businesspeople should be aware that decisions involving ethics are pertinent to them because any ethical issue can affect their business, and unethical actions can damage the reputation of the community, customers, suppliers, and the investors of their business. Not complying with ethical practices can harm the goodwill and credibility of the concerned businessperson, and lead to the loss of trust, respect, and confidence towards businesspeople in general.

Norasmah Othman/ (Assoc. Prof. Dr)

line 1 Universiti Kebangsaan Malaysia line 2: Malaysia
The majority of Bumiputera in Malaysia are Muslims. Practicing good ethics in business is given due importance in Islamic teachings, where the concept of business does not simply involve the transactions of buying and selling. For Muslims, business is a form of ibadah (work that invokes Allah's blessings) to gain profit that is halal (permitted item under Muslim law), and at the same time, fulfill human needs. It involves the concept of helping (surah al-Maidah: 2) and not cheating one another (surah alNisa': 29). Ethics in Islam are based on faith in Allah s.w.t., being responsible and trustworthy, and not getting involved in business that is haram (matters forbidden in Islam), such as gambling, alcohol, and corruption [3].

According to the Ministry of Domestic Trade and Consumer Affairs, in 2008, there were various reports on unethical business practices. The reports show that there has been an increase in unethical practices by businesspeople and entrepreneurs. This is evident in the fact that 9,070 complaints were received in 2008 compared to 6,455 in 2007 (an increase of 26.25\%) [4]. This scenario is not healthy and should receive immediate attention.

\section{Problem Statement}

The contemporary business world faces various issues related to business ethics. Despite the progress made, problems related to business ethics continue to rise periodically [5]. Misconduct in businesses can be attributed to the greed of businesspeople and their incapability of managing their wealth and business assets wisely. The capitalist system is widely implemented in the business world, which often provides opportunities for businesspeople to get rich quickly and easily. In such systems, businesspeople forget their responsibilities towards society and are tempted to violate business ethics for profit and greed [6]. Avoiding tax payments [7] and running illegal businesses are some examples of unethical business practices. Usually, people try to establish their business such that they can reap as much profit as possible. Another example of an unethical business practice is providing incorrect or manipulated information on labels and food packaging; this is carried out by not displaying the actual content, manipulating the information on the measure and weight, bribing the authorities, and providing inaccurate information to vendors. Falsifying the expiry date of a product, misusing the halal sign, creating advertisements that misguide the audience about the true purpose of the product, and not declaring the presence of certain substances in product from consumers are some of the other common unethical business practices [8].

Throughout history, ethical problems have plagued people across the world in every aspect of life, including in business practices. This is because the proliferation of business depends on consumer demand. Consumer 
awareness in Malaysia is low [9]. Consumers still seek the cheapest but best service regardless of who the suppliers are. Muslim consumers are often confused by the legitimacy of the halal-haram items (permitted and forbidden items under Muslim law [10]. The use of gelatin in a variety of items such as photographic paper, x-ray films, gum, blood plasma, insulin, medications, capsules, and food preservatives, and food items such as bread, vitamin, fast food, snacks, ice creams, and dairy products, is of concern to Muslims. This is because $80 \%$ of the gelatin found in the market is made from pork fat, which is cheap and easily available. However, there are some limitations to enforcing the authenticity of halal-haram products, and businesspeople take advantage of the situation when dealing with products that are actually haram [11]. For example, the entire line of Old Town restaurants put up halal signs to attract Muslim customers. A majority of the halal signs are displayed by non-Muslimowned businesses. If not verified or used lawfully, users may not know the origin of the products used by such restaurants and could end up being victims.

In addition, the way businesspeople interact with others within the settings of their businesses is also one of the causes of unethical business practices, such as ignorance in maintaining the sanctity of halal products. The [12] reported that halal products and services are no longer the concern of Islamic countries alone. This is because the Muslim population has reached 1.6 billion worldwide. Therefore, the halal guarantee has now become a universal symbol that Muslims should be able to trust without any hesitation, and products that have the halal label on it should conform to quality standards. The increase in awareness among non-Muslims of the importance of halal food promotes halal products, which is seen as a symbol of safety and quality. This statement is supported by statistical data obtained from the Department of Islamic Development Malaysia (JAKIM), which shows that about $80 \%$ of the applications for the halal certification were by non-Muslims. It is clear that non-Muslim businesspeople are far ahead in terms of the production and marketing of halal food [13]. Therefore, the issue continues to be a lawful thing accepted by non-Muslims, because of their knowledge and experience in running a business.

In this era of globalization, foreign companies are likely to flood the local markets with various products. They come up with products that are of better quality, better branded, sophisticatedly manufactured, and well design and have all kinds of features. This phenomenon will result in an abundance of local products in the market. Local businesses will not be able to compete with foreign companies because of foreign companies always has lower production costs [14]. Thus, the local or global economic challenges now compel businesspeople to be more competitive, proactive, and dynamic. For example, owing to a large, well-planned network, counterfeiting and piracy are still prevalent in Malaysia. The products are much cheaper and the quality is as good as that of the original, as a result of which the demand for these products is sustained. Businesspeople make millions of dollars from such activities, so it is difficult for them to not practice them.

This paper reports on the practice of business ethics among SMEs in the district of Kajang, Selangor, Malaysia.
Based on the problem statement discussed earlier, we try to answer the following research questions:

1. To what extent are business ethics practiced among SMEs in Kajang, Selangor?

2. Is there a difference in the practice of business ethics between the Bumiputera and the nonBumiputera-owned SMEs?

\section{Research Method}

\section{A. Research Design and Sampling}

A survey method was used in this study. The population of this study was initially intended to include all the SMEs in Selangor, Malaysia. However, according to [15], no detailed data are available on the number of businesspeople who own SMEs in the state. Therefore, this study has been conducted in an area where the data on SMEs were available. We selected the Kajang district, Selangor because a list of businesspeople names or companies of registered businesses until 2009 is available. The total population of businesspeople with SMEs registered in the Kajang area until 2009 is 259. The sample size of this study was 100 . The sample size was calculated using methods outlined by [16] and the selection was made randomly, with $50 \%$ of the sample being Bumiputera and the remaining being nonBumiputera businesspeople. Such a selection is made to achieve the research objectives, which is to identify the level of and differences between business ethics practiced by the Bumiputera and non-Bumiputera businesspeople. The Bumiputera samples represent the Malay community, while the non-Bumiputera samples are businesses owned by the Chinese and Indian communities.

\section{B. Instruments}

This quantitative study used a questionnaire to obtain data. The questionnaire items were developed based on a literature review of past research and by referring to the work of [17]. The questionnaire was divided into two parts: Part A profiled the respondents with regard to traits such as gender and race, while Part B measured the extent to which business ethics were practiced among SMEs. Business ethics among SME owners is viewed from four dimensions: personal values (9 items), managing social responsibilty (5 items), way of conducting business (6 items), and interaction with society (9 items). A 5-point Likert scale was used in this study, where 1 = "strongly disagree" and $5=$ "strongly agree."

Criticism and comments from experts were sought to strengthen the questionnaire statements with regard to the language used and the clarity of purpose of each item (content validity and face validity). After modifications were made, in June 2010, a pilot study was conducted on 30 respondents who owned SMEs in an industrial area in Sungai Buloh, Selangor, Malaysia. The study duration was about three weeks. All 30 questionnaires were received and analyzed for realibility. The Cronbach Alpha was used to 


\begin{tabular}{clcl}
\hline No & Dimensions & Mean & Level \\
\hline 1 & Personal values & 4.48 & High \\
\hline 2 & $\begin{array}{l}\text { Managing } \\
\text { responsibility }\end{array}$ & 3.53 & $\begin{array}{l}\text { Moderately } \\
\text { High }\end{array}$ \\
\hline 3 & $\begin{array}{l}\text { Ways of conducting } \\
\text { business }\end{array}$ & 3.16 & $\begin{array}{l}\text { Moderately } \\
\text { High }\end{array}$ \\
\hline 4 & $\begin{array}{l}\text { Interaction with others } \\
\text { in business settings }\end{array}$ & 3.99 & $\begin{array}{l}\text { Moderately } \\
\text { High }\end{array}$ \\
\hline
\end{tabular}

measure the instrument reliability and finally the results show that all aspects for Section B exceeded 0.7. According to [17], questionnaires with Cronbach Alpha value of at least 0.7 can be used. The alpha value of our instrument was 0.74 , and the validity of each item was over 0.3 . This meant that this instrument could be used for this study.

\section{Data Analysis}

The data obtained were analyzed using the statistical analysis tool SPSS (Statistical Package for Social Sciences) for Windows v. 18.0. In this study, two types of statistics-descriptive and inferential-were used to measure the level of ethical business practices among SMEs. The mean score interpretations can be found in Table 1 .

Table 1: Mean score interpretation

\begin{tabular}{ll}
\hline Mean Score & Level \\
\hline $1.00-2.00$ & Low \\
\hline $2.01-3.00$ & Moderately Low \\
\hline $3.01-4.00$ & Moderately High \\
\hline $4.01-5.00$ & High \\
\hline
\end{tabular}

\section{Profile of Respondent}

Table 2 shows a gender and race-based distribution of the SME businesspeople involved in this study. This study involved $52(52 \%)$ male and $48(48 \%)$ female traders, among whom 50 were Malay (Bumiputera), and from the remaining, $32(32 \%)$ were Chinese and 18 (18\%) were Indian (non-Bumiputera).

Table 2: Respondents' demographic profiles

\begin{tabular}{|c|c|c|c|}
\hline & Variables & Frequency & Percentage \\
\hline \multirow[t]{2}{*}{ Sex } & Male & 52 & 52.0 \\
\hline & Female & 48 & 48.0 \\
\hline \multirow{4}{*}{ Race } & $\begin{array}{c}\text { Bumiputera: } \\
\text { Malays }\end{array}$ & 50 & 50.0 \\
\hline & Non Bumiputera: & & 50.0 \\
\hline & Chinese & 32 & \\
\hline & Indians & 18 & \\
\hline
\end{tabular}

\section{v. Finding of Discussion}

\section{A. Research Question 1: To what extent are business ethics practiced by SMEs in Kajang, Selangor?}

Table 3: Level of business ethics among SME
Table 3 gives an overview of the business ethics practiced by SMEs in Kajang, Selangor. Of the four dimensions tested for business ethics practices among the respondents, it was found that only personal values showed a high mean value, the highest compared to the mean values of other dimensions as social responsibility management, the way of conducting business, and interacting with others in their business settings, which had moderately high levels of mean.

\section{B. Research question 2: Is there any difference in the business ethics practices among Bumiputera and non- Bumiputera SMEs?}

Table 4 gives a comprehensive overview of business ethics practiced by SMEs. One research question aims to explore whether there are differences in the practice of business ethics between Bumiputera and non-Bumiputera SMEs. The data were analyzed using a t-test to determine the extent of business ethics practiced in the four dimensions.

Table 4: t-test based on race

\begin{tabular}{lccccc}
\hline Race & $\mathbf{n}$ & Mean & sd & $\begin{array}{l}\text { t- } \\
\text { value }\end{array}$ & Sig \\
\hline \multicolumn{7}{l}{ i. dimension of personal values } \\
\hline Bumiputera & 50 & 2.61 & 0.52 & 1.00 & 0.32 \\
\hline Non-Bumiputera & 50 & 2.56 & 0.46 & & \\
\hline ii. dimension of managing social responsibility & \\
\hline $\begin{array}{l}\text { Bumiputera } \\
\text { Non-Bumiputera }\end{array}$ & 2.91 & 0.12 & -1.80 & 0.07 & 2.91 \\
\hline iii. ways of conducting business & 0.20 & & & 2.80 \\
\hline Bumiputera & 2.70 & 0.56 & -2.14 & 0.03 & 2.70 \\
\hline Non-Bumiputera & 2.70 & 0.56 & & & \\
\hline
\end{tabular}

\section{Differences in the dimension of personal values}

Ho. 1: There is no significant difference between Bumiputera and non-Bumiputera businesspeople in the dimension of personal values

The t-test results outlined in Table 4 (i), show that there is no significant difference between the Bumiputera and non-Bumiputera businesspeople in terms of their personal values $(\mathrm{t}=1.00, \mathrm{sig}=0.32, \mathrm{p}>0.05)$ This supports Ho. 1. There is no significant difference in the means of non-Bumiputera and Bumiputera respondents (2.61 and 2.56 respectively). Both races have the same or similar personal values in matters relating to self-correction, not giving up, not trusting others easily, not telling lies, not begging, not being satisfied with an achievement easily, and fulfilling promises, all being good business ethics. 
These findings are supported by [17], who shows that both Bumiputera and non-Bumiputera businesspeople with high ethical values such as honesty, sincerity, and trust (personal values) in business will gain the trust of consumers, which, in turn, can improve business stability and performance. This view is also held in a study by [18], according to whom there is a relationship between personal values and leadership in the context of running an organization smoothly.

A study by [19] on 512 entrepreneurs also showed that there was a positive relationship between an entrepreneur's personal values and the success of his or her business. Similarly, [20] conducted a study based on the observation of and interviews with 226 Malay entrepreneurs and found that to be successful in business, one needs to have a sound sense of self-worth and good personal values. These values are important because they help gain trust and eventually, loyal customers [21]. A successful businessperson in history was the Prophet Muhammad. His business practices were rooted in diligence and hard work, honesty, and fairness. This is evident in the titles given to him - the trusted (al-Amin) and the honest (al-Sidiq) [22].

According to [22], moral or ethical values, based on specific principles and concepts, reflect the integrity and nobleness of an organization. Values such as honesty, openness, transparency, and responsibility, as well as a caring attitude, contribute towards the stability of an organization. Thus, this study shows that it is not surprising that the two races (Bumiputera and non-Bumiputera) have similar personal values.

\section{Differences in the dimension of managing social responsibility}

Ho. 2: There is no significant difference between Bumiputera and non-Bumiputera businesspeople in the dimension of managing social responsibility.

Table 4(ii) shows the t-test results on the difference in the managing social responsibility practices of Bumiputera and non-Bumiputera businesspeople. These findings imply that there is no significant difference in the aspects of managing social responsibility between Bumiputera and non-Bumiputera businesspeople since the $\mathrm{t}$-value $=-1.80$, sig. $\mathrm{p}=0.07, \mathrm{p}>0.05$ ). Therefore, Ho. 2 is supported.

In general, these findings indicate that both races adopted the same or similar approach towards managing social responsibility. This proves that some flexibility can be adopted when practicing managing social responsibility. Businesspeople try their best to manage social responsibility ethically, but occasionally, they have to adopt a different approach to adhere to certain procedures to meet local needs. This is consistent with the findings of a study by [20] involving over 108 businesspeople from the state of Perlis. Their findings show that the Muslim businesspeople had a very low level of compliance towards the payment of zakat in Perlis. This indicates that the need to pay zakat every year is not taken seriously by businesspeople.
According to [17], zakat refers to a blessing, growth, cleanliness, or goodness. According to the tenets of Islam, zakat is intended to help the poor by transferring a part of the revenue or assets of the rich to the poor. This system is intended to foster honesty and trustworthiness among people. The Prophet explained that it is not desirable to gather wealth and spend it on nonessential things, rather than on charity. Businesspeople are prohibited from wasting God-given wealth such as property, time, and convenience. If a businessperson is stingy, extravagant, or wasteful, the path that leads him to wealth will be narrow. All three acts lead to wealth reduction and the stunting of financial growth. This statement reflects the low understanding and subsequent underestimation of the need to pay zakat among businesspeople in Perlis .

A similar case was found among non-Muslim businesspeople in a study by [23]. These studies found that non-Muslim businesspeople are not very concerned about tax payment. This shows that Muslim and non-Muslims have a similar attitude toward the payment of zakat or taxes. [19] found that managing social responsibility efficiently and effectively as well as applying Islamic values in businesses are perceived as practices that invoke blessings for Muslims, leading to an increase in their wealth. This concept is slightly different for non-Bumiputera businesses that pay taxes, not zakat. It is necessary to calculate tax because it can affect the performance and the longevity of a business.

\section{E. Differences in the dimension of conducting business}

Ho. 3: There is no significant difference between Bumiputera and non-Bumiputera businesspeople in their way of conducting business.

The results, as shown in Table 4 (iii), indicate that there is a significant difference in the mean scores of the $t$ tests for Bumiputera and non-Bumiputera businesspeople in the way they conduct business. Data shows that the t-value = -2.14 , sig $=0.03, \mathrm{p}<0.05$. Thus, Ho. 3 is not supported. More interestingly, the practice of ethics in doing businesses is higher among Bumiputera (mean: 2.70) than among nonBumiputera businesspeople (mean: 2.67).

According to [24], in this era of globalization, trade liberalization, coupled with the proliferation of science and technology, has brought about a sudden change in the world trade markets and an increase in the effectiveness of competition. Increasing globalization poses new challenges to the social and legal aspects of businesses and consequently, the principles of ethics in business is no longer a priority while dealing with consumers. The sales and packaging of consumer products in the market are becoming increasingly complex, thus making it more difficult to determine the safety level of the products . [25] found that defects in consumer products have increased, leading to an increase in diseases caused by defective products. To this day, users continue to purchase items that they need even if the information on the label is insufficient. 
Businesses are aware of this and they take this opportunity to oppress consumers in various ways.

[21] believe that a competitive market could enhance consumer welfare. However, a significant market failure can deviate a company from healthy competition and thus make it incapable of contributing to the prosperity and welfare of consumers. This is because the degree of competition in the market affects the welfare of both consumers and the businesses in the market. These findings imply that high ethical standards can measure the success of a businessperson. This is necessary because businesspeople always encounter new things. Thus, negative practices like engaging in corrupt activities and manufacturing low-quality products should be rejected by businesspeople. Ethical practices will help them win the trust of customers, suppliers, and shareholders.

According to [2], many complaints have been made regarding the ethical problems associated with corruption and breach of trust among businesspeople, regardless of race and nation.

\section{E. Difference in the dimension of interaction with others in business settings}

\author{
Ho. 4: There is no significant difference between \\ Bumiputera and non-Bumiputera businesspeople in the \\ dimension of interaction with others in their business \\ settings.
}

This hypothesis is meant to determine whether there were any differences with regard to the interaction style of non-Bumiputera and Bumiputera businesspeople in their business settings. Findings have shown that there is no significant difference in the way Bumiputera and nonBumiputera businesspeople interact with others in business settings $(\mathrm{t}=0.29$, sig $=0.21, \mathrm{p}<0.05)$. Thus, Ho. 4 is supported. This finding is supported by [26], who states that businesspeople need to be considerate and respectful to create a positive interaction with others, in this case, the workers or customers. Good relationships among employees create a positive work environment and improve productivity, and a good relationship with customers can widen or strengthen business networks.

According to [27], a business has to bear some risks if it wishes to seek a profit. However, businesses with good ethics will gain a competitive advantage and become well known. Therefore, businesspeople should not look down on interacting with others in society or in their business setting because it has a significant influence on company performance and continuity.

According to [28], ethics is a form of trust. Business decisions should take into account social and economic interests. [29] believes that many businesspeople fail to achieve their business goals because of their unethical behavior, which is often noticed by the public. The practice of ethical interaction with others in a business setting ensures that businesses are better able to maintain a good image of their company and help the company maintain their existing customer base besides attracting potential customers. This opinion is consistent with [30] finding that the image of a business has become an important element in improving business performance. The results of the t-test on the interaction with people in business settings and race can be seen in Table 7

\section{vi. Conclusion}

In recent times, ethics has become one of the most important factors that need to be addressed by all businesspeople to ensure that they continue and succeed in their businesses. This is because, lately, there have been many reports that reveal that many businesspeople are dishonest in their business dealings, thus leading to distrust in their businesses by customers. This will eventually lead to the closure of the businesses.

Therefore, this study investigated the extent to which business ethics are practiced among the SMEs in an area in Selangor. The study also attempted to determine whether there are differences in the business ethics practices among the Bumiputera and non-Bumiputera businesspeople. The study found that, in general, regardless of race, SME businesspeople are aware of the importance of ethics in business. The data showed that the overall level of business ethics among Bumiputera and non-Bumiputera-owned SMEs is between high and moderately high. Most traders believe that practicing good ethics in business is equivalent to having good personal ethical values, managing social responsibility, and conducting business correctly, and these have a positive bearing on the success of their business. However, there is room for improvement in the practice and level of confidence of business ethics by businesspeople so that it guides their behavior in all situations.

\section{References}

[1] Yusof, A. A. and A. Bashir, 2008. The management of Islamic businesses. Sintok: Universiti Utara Malaysia.

[2] Hartman, L. P., 2005. Perspectives in business ethics. 3re Edn., New York: McGraw Hill/Irwin.

[3] Endot, I., 2006. Perancangan pembangunan Malaysia. Kajian dasar dan strategi. Shah Alam: Pusat Penerbit Universiti.

[4] Ministry of Domestic Trade and Consumer Affairs. 2009. Annual Report, 2009.

[5] Rice, G., 2008. Islamic ethics and the implications for business. Journal of Bussiness Ethics, 18: 345-358

[6] Ministry of Environment. 2008. Annual Report, 2008.

[7] Inland Revenue Board. 2008. Annual Report, 2008.

[8] Aziz, A. A. and Z. A. M. Hussein, 2009. Biotechnological impacts on consumer protection: legal aspects in relation to product safety. Jurnal Pengurusan, 29: 35-56.

[9] Ministry of Domestic Trade and Consumer Affairs. 2008. Annual Report, 2008.

[10] Hall, G. and K. A. Wahab, 2007. Influence on the survival and failure of small firms in Malaysia. 
International Journal of Business and Globalization, 1(1): 88-108.

[11] Department of Islamic Development Malaysia. 2010. Annual Report 2010

[12] Jurnal Halal Malaysia, 2007. Halal Malaysia Islamic Capital Market \& Financial Services. Kuala Lumpur: Islamic Dakwah Foundation Malaysia

[13] Utusan Malaysia, 2007. Malaysia Exports Halal Expertise.

[14] Fassin, Y., 2005. The reason behind non-ethical behavior in business and entrepreneurship. Journal of Bussiness Ethics, 60: 265-279

[15 Muhammad, M. Z., A. Ilias, M. F. Ghazali, R. C. Abdullah, and H. Amin, 2008. An analysis of Islamic ethics in small and medium enterprises (SMEs). UNITAR e-Journal, 4: 44-53.

[16] Sekaran, U., 2003. Research methods for business: a skill building approach. Edisi keempat. New York: John Wiley \& Sons.

[17] Wahid, H., S. Ahmad, and M. A. M. Noor, 2007. Awareness of paying zakat in Malaysia. Islamiyyat, 29: 53-70.

[18] Herzfeld, T. and C. Weiss, 2003. Corruption and legal (in)effectiveness: an empirical investigation. Eur. $J$. Polit. Econ., 19 (3): 621-632.

[19] Wahid, H., M. A. M. Noor, and S. Ahmad, 2005. The awareness of paying zakat: what are the factors? International Journal of Management Studies, 12 (2):171-189.

[20] Yusof, A. A. and A. Bashir, 2008. The management of Islamic businesses. Sintok: Universiti Utara Malaysia.

[21] Kubenka, M. and R. Myskova, 2009. The B2B market: corporate social responsibility or corporate social responsiveness? WSEAS Transactions On Business And Economics, 6: 11.

[22] Muhammad, M. Z., A. Ilias, M. F. Ghazali, R. C. Abdullah, and H. Amin, 2008. An analysis of Islamic ethics in small and medium enterprises (SMEs). UNITAR e-Journal, 4: 44-53

[23] Bobek, D. D. and R. C. Hatfield, 2003. An investigation of the theory of planned behavior and the role of moral obligation in tax compliance. Behavioral Research in Accounting, 15: 13-38

[24] Skrlec and Vlahovic, 2010. Impact of change management implementation in a production system-a Croatian experience. WSEAS Transactions on Business and Economics, 1:7.

Small and Medium Industries Development Corporation. 2007. Annual Report, 2007.

[25] Majid, M. Z. A., 2003. The role of Islamic law in building Malay civilization. Jurnal YADIM. Yayasan Dakwah Islamiah Malaysia.

[26] Kralj, D., 2009. Green environmental business. WSEAS Transactions on Business and Economics.

[27] Everett, J., D. Neu, and A. S. Rahamas, 2006. The global fight against corruption: a Foucaultian virtues ethics framing. J. Bus. Ethics, 6 (5): 1-12.

[28] Vitell, S. J., A. Bakir, J. G. P. Paolillo, E. R. Hidalgo, J. Al-Khatib, and M. Y. A. Rawwas, 2003. Ethical judgments and intentions: a multinational study of marketing professionals. European Review, 12(2): 151-171

[29] Beekun, R. I. and J. A. Badawi, 2005. Balancing ethical responsibility among multiple organizational stakeholders: the Islamic perspective. Journal of Bussiness Ethics, (60): 131-145.

[30] Hamilton, J. B., S. B. Knouse, and V. Hill, 2009. Google in China: a manager-friendly heuristic model for resolving cross-cultural ethical conflicts. Journal of Bussiness Ethics, 2: 60-77.

About Author (s):

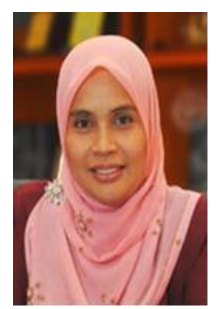

Norasmah Othman is an associate professor at Universiti Kebangsaan Malaysia. She's teaching entrepreneurship education and measurement. 